\title{
Percepcja szans i zagrożeń w polskich przedsiębiorstwach w kontekście wykorzystania outsourcingu - rezultaty badań ${ }^{1}$
}

\author{
Dr Jakub Drzewiecki \\ Uniwersytet Ekonomiczny we Wrocławiu, Wydział Zarządzania \\ Katedra Teorii Organizacji i Zarządzania
}

\section{Wprowadzenie}

Wśród licznych celów outsourcingu, będącego jedną z najpopularniejszych metod zarządzania ${ }^{2}$, wyróżnić należy adaptację organizacji do wymagań jej otoczenia. Metoda ta umożliwia w szczególności modyfikację granic zewnętrznych organizacji, między innymi po to, by umożliwić jej wykorzystanie szans oraz zniwelowanie zagrożeń 3 . W tym miejscu należy wskazać na dwa istotne problemy badawcze. Pierwszy z nich dotyczy postrzegania znaczenia poszczególnych szans oraz zagrożeń przez polskie przedsiębiorstwa. Wydaje się, iż ocena dokonywana w tym zakresie przez menedżerów będzie mieć kluczowe znaczenie dla podejmowanych przez nich decyzji, w tym stosowanych metod zarządzania. Natomiast problem drugi dotyczy wpływu sposobu, w jaki polskie przedsiębiorstwa oceniają szanse i zagrożenia, na wybory w obszarze outsourcingu. W szczególności należy skierować uwagę na dwa główne aspekty decyzyjne: wybór stopnia, w jakim wykorzystywany będzie w danej organizacji outsourcing, jak również sposób jego implementacji. Oba te zagadnienia będą bowiem wpływać zarówno na skuteczność, jak i efektywność outsourcingu.

1 Projekt został sfinansowany ze środków Narodowego Centrum Nauki przyznanych na podstawie decyzji numer DEC-2013/09/D/HS4/00583.

2 J. Drzewiecki, Outsourcing application effectiveness in Polish enterprises - research results, „Przegląd Organizacji” 2017, nr 12, s. 67-75.

3 S. Cyfert, Granice organizacji, Wydawnictwo Uniwersytetu Ekonomicznego w Poznaniu, Poznań 2012; J. Drzewiecki, Outsourcing jako narzędzie zmiany modelu biznesu: perspektywa Business Model Canvas, Wydawnictwo Uniwersytetu Ekonomicznego we Wrocławiu, Wroctaw 2019, s. 262-263. 
Celem artykułu jest identyfikacja oraz analiza ewentualnego wpływu percepcji uwzględnionych w badaniu szans oraz zagrożeń w polskich przedsiębiorstwach na dwie podstawowe charakterystyki outsourcingu: zakres oraz dojrzałość. Opracowanie zawiera prezentację wyników badań ilościowych przeprowadzonych na próbie 281 polskich przedsiębiorstw z wykorzystaniem kwestionariusza ankiety oraz metod pomocniczych (np. CATI). Jako metody analizy zgromadzonych w ten sposób danych wykorzystano natomiast $w$ artykule statystyki opisowe oraz analizę korelacji. W badaniach posłużono się autorskimi koncepcjami pomiaru zakresu oraz dojrzałości outsourcingu, opisanymi pokrótce w kolejnym punkcie.

\section{Charakterystyka próby badawczej oraz metodyka przeprowadzonych badań}

Próba badawcza objęła 281 przypadków i miała charakter celowy. Podstawowym, w kontekście tematyki artykułu, kryterium doboru podmiotu do próby było wykorzystanie outsourcingu. Dodatkowo na tym etapie badań przyjęto dwa kryteria wynikające ze specyfiki projektu badawczego, z którego finansowane były badania:

- pochodzenie kapitału: badaniem zostały objęte przedsiębiorstwa polskie4;

- wielkość zatrudnienia: badano przedsiębiorstwa zatrudniające co najmniej dziesięciu ${ }^{5}$ pracowników 6 .

- Syntetyczną charakterystykę próby badawczej ukazuje tabela 1.

Tabela 1. Charakterystyka próby badawczej w przekroju wybranych cech jakościowych

\begin{tabular}{|l|r|r|r|c|}
\hline \multirow{2}{*}{ Forma organizacyjno-prawna prowadzonej działalności } & \multicolumn{3}{|c|}{$\begin{array}{c}\text { Wielkość } \\
\text { przedsiębiorstwa }\end{array}$} & \multirow{2}{*}{ Suma (\%) } \\
\cline { 2 - 5 } & Małe & Średnie & \multicolumn{1}{c|}{ Duże } & \\
\hline Przedsiębiorstwo państwowe & 1 & 2 & 7 & $10(3,6 \%)$ \\
\hline Spółka akcyjna & 3 & 5 & 19 & $27(9,6 \%)$ \\
\hline Spółka cywilna & 21 & 50 & 13 & $84(29,9 \%)$ \\
\hline Spółka jawna & 12 & 9 & 4 & $25(8,9 \%)$ \\
\hline Spółka komandytowa & 0 & 0 & 1 & $1(0,3 \%)$ \\
\hline Spółka z ograniczoną odpowiedzialnością & 22 & 20 & 24 & $66(23,5 \%)$ \\
\hline
\end{tabular}

4 Pojęciem „polskie przedsiębiorstwo” określano podmiot gospodarczy, którego dominującymi (większościowymi) właścicielami są w przypadku osób fizycznych obywatele Polski, a w przypadku osób prawnych przedsiębiorstwa z dominującym kapitałem polskim, Skarb Państwa lub polskie jednostki samorządu terytorialnego.

5 Warunkiem zakwalifikowania przedsiębiorstwa do próby było łączne spełnienie wskazanych trzech kryteriów.

6 J. Drzewiecki, Sposoby realizacji outsourcingu stosowanego w polskich przedsiębiorstwach - wyniki badań, „Organizacja i Kierowanie” 2018, nr 1, s. 113-129. 


\begin{tabular}{|l|r|r|r|c|}
\hline $\begin{array}{l}\text { Zakład osoby fizycznej prowadzącej działalność } \\
\text { gospodarczą }\end{array}$ & 44 & 23 & 1 & $68(24,2 \%)$ \\
\hline Suma & 103 & 109 & 69 & $\mathbf{2 8 1}(\mathbf{1 0 0 \% )}$ \\
\hline Obszar działalności & & & & \\
\hline Działa tylko na rynku krajowym & 66 & 72 & 30 & $168(59,8 \%)$ \\
\hline W głównej mierze działa na rynkach zagranicznych & 2 & 3 & 5 & $10(3,6 \%)$ \\
\hline W głównej mierze działa na rynku krajowym & 35 & 34 & 34 & $103(36,6 \%)$ \\
\hline Suma & 103 & 109 & 69 & $\mathbf{2 8 1 ( 1 0 0 \% )}$ \\
\hline Stopień dywersyfikacji & & & & \\
\hline Firma prowadzi działalność w jednym sektorze (branży) & 53 & 52 & 21 & $126(44,8 \%)$ \\
\hline $\begin{array}{l}\text { Firma prowadzi działalność w kilku sektorach (branżach) } \\
\text { spokrewnionych ze sobą }\end{array}$ & 45 & 53 & 31 & $129(45,9 \%)$ \\
\hline $\begin{array}{l}\text { Firma prowadzi dziatalność w kilku sektorach (branżach) } \\
\text { niespokrewnionych ze sobą }\end{array}$ & 4 & 3 & 7 & $14(5 \%)$ \\
\hline $\begin{array}{l}\text { Firma prowadzi działalność w kilkunastu sektorach } \\
\text { (branżach) }\end{array}$ & 1 & 1 & 10 & $12(4,3 \%)$ \\
\hline Suma & 103 & 109 & 69 & $\mathbf{2 8 1 ( 1 0 0 \% )}$ \\
\hline
\end{tabular}

Źródło: J. Drzewiecki, Sposoby realizacji outsourcingu stosowanego w polskich przedsiębiorstwach - wyniki badań, „Organizacja i Kierowanie” 2018, nr 1, s. 115.

Przygotowanie kwestionariusza poprzedził etap badań wstępnych, w którym zidentyfikowano listę dwunastu szans oraz zagrożeń uwzględnionych w badaniu. Kierowano się tutaj dwoma podstawowymi kryteriami. Pierwsze z nich dotyczyło możliwie jednoznacznego zakwalifikowania danego zjawiska jako szansy lub zagrożenia przez respondentów, tak by uniknąć między innymi problemu subiektywizmu w ocenie zmian zachodzących w środowisku danego podmiotu. Jednocześnie poszukiwano zjawisk uniwersalnych, to znaczy takich, które są istotne dla możliwie najszerszej grupy podmiotów gospodarczych, co wynikało ze zróżnicowania przedsiębiorstw $\mathrm{w}$ próbie względem cech jakościowych uwzględnionych w tabeli 1.

W dalszej kolejności zadano respondentom dwa pytania dotyczące prawdopodobieństwa wystąpienia poszczególnych szans i zagrożeń oraz siły ich wpływu na sytuację danego podmiotu. Do pomiaru wykorzystano skalę porządkową sześciostopniową od 0 („minimalne prawdopodobieństwo wystąpienia”) do 5 („,niemal pewne pojawienie się szansy/zagrożenia”). Następnie, aby zmierzyć znaczenie określonej szansy lub zagrożenia dla danego podmiotu, pomnożono oba wspomniane wskaźniki (prawdopodobieństwo wpływu $\times$ siła wpływu) ${ }^{7}$. Zidentyfikowane szanse oraz zagrożenia, wraz z poziomem odpowiadających im zmiennych, przedstawiono w tabeli 2 .

$7 \quad$ Wartość zmiennych odpowiedzialnych za pomiar znaczenia szans oraz zagrożeń kształtowała się zatem w przedziale między 0 a 25. 
Tabela 2. Znaczenie szans i zagrożeń dla podmiotów w próbie

\begin{tabular}{|c|c|c|c|c|c|}
\hline Rodzaj szansy & $\begin{array}{c}\text { Śred- } \\
\text { nia }\end{array}$ & $\begin{array}{c}\text { Me- } \\
\text { diana }\end{array}$ & Rodzaj zagrożenia & $\begin{array}{c}\text { Śred- } \\
\text { nia }\end{array}$ & $\begin{array}{l}\text { Me- } \\
\text { diana }\end{array}$ \\
\hline $\begin{array}{l}\text { Wyższy poziom zintegrowania } \\
\text { produktów i/lub usług }\end{array}$ & 3,77 & 2,00 & $\begin{array}{l}\text { Pojawienie się usług/ } \\
\text { produktów substytucyjnych }\end{array}$ & 4,53 & 4,00 \\
\hline $\begin{array}{l}\text { Dokładniejsze dopasowanie } \\
\text { produktów/usług do potrzeb } \\
\text { klientów }\end{array}$ & 6,28 & 4,00 & $\begin{array}{l}\text { Pojawienie się nowych } \\
\text { konkurentów }\end{array}$ & 7,59 & 6,00 \\
\hline $\begin{array}{l}\text { Pogorszenie jakości } \\
\text { produktów/usług } \\
\text { konkurentów }\end{array}$ & 4,04 & 3,00 & $\begin{array}{l}\text { Doskonalenie produktów/ } \\
\text { usług konkurentów }\end{array}$ & 5,77 & 4,00 \\
\hline $\begin{array}{l}\text { Pojawienie się nowych } \\
\text { potencjalnych segmentów } \\
\text { klientów }\end{array}$ & 4,66 & 4,00 & $\begin{array}{l}\text { Wystąpienie zakłóceń } \\
\text { w dostawach zasobów } \\
\text { niezbędnych do dziatalności } \\
\text { podmiotu }\end{array}$ & 4,83 & 4,00 \\
\hline $\begin{array}{l}\text { Odejście klientów } \\
\text { od konkurentów }\end{array}$ & 6,24 & 4,00 & $\begin{array}{l}\text { Nagła utrata kluczowego } \\
\text { zasobu }\end{array}$ & 4,74 & 4,00 \\
\hline $\begin{array}{l}\text { Pojawienie się nowych } \\
\text { potencjalnych dostawców/ } \\
\text { partnerów biznesowych }\end{array}$ & 5,31 & 4,00 & $\begin{array}{l}\text { Wzrost cen kluczowych } \\
\text { zasobów }\end{array}$ & 4,90 & 4,00 \\
\hline $\begin{array}{l}\text { Możliwość wykorzystania } \\
\text { kanatów partnerów }\end{array}$ & 3,53 & 2,00 & $\begin{array}{l}\text { Utrata klientów na rzecz } \\
\text { dotychczasowego konkurenta }\end{array}$ & 6,00 & 4,00 \\
\hline $\begin{array}{l}\text { Możliwość tańszego } \\
\text { pozyskania zasobów } \\
\text { kluczowych dla podmiotu }\end{array}$ & 4,42 & 4,00 & $\begin{array}{l}\text { Utrata klientów w efekcie } \\
\text { pojawienia się produktów/ } \\
\text { usług substytucyjnych }\end{array}$ & 4,74 & 4,00 \\
\hline $\begin{array}{l}\text { Możliwość bardziej } \\
\text { efektywnego wykorzystania } \\
\text { posiadanych zasobów }\end{array}$ & 5,01 & 4,00 & Utrata kluczowego partnera & 4,20 & 4,00 \\
\hline $\begin{array}{l}\text { Możliwość większej } \\
\text { standaryzacji działań }\end{array}$ & 3,80 & 4,00 & $\begin{array}{l}\text { Nawiązanie współpracy } \\
\text { przez kluczowego partnera } \\
\text { z konkurencją }\end{array}$ & 4,44 & 4,00 \\
\hline $\begin{array}{l}\text { Możliwość wprowadzenia } \\
\text { nowej technologii }\end{array}$ & 6,67 & 6,00 & $\begin{array}{l}\text { Nadmierne uzależnienie się } \\
\text { od partnera }\end{array}$ & 3,11 & 1,00 \\
\hline Zacieśnienie relacji z klientami & 7,80 & 8,00 & Pogorszenie relacji z klientami & 4,84 & 4,00 \\
\hline
\end{tabular}

Źródło: opracowanie własne na podstawie J. Drzewiecki, Outsourcing jako narzędzie zmiany modelu biznesu: perspektywa Business Model Canvas, Wydawnictwo Uniwersytetu Ekonomicznego we Wrocławiu, Wrocław 2019, s. 262-263.

Za najistotniejsze szanse badane przedsiębiorstwa uznały: zacieśnienie relacji z klientami, możliwość wprowadzenia nowej technologii, dokładniejsze dopasowanie produktów/usług do potrzeb klientów oraz odejście klientów od konkurentów. Jako najmniej istotne szanse wskazano natomiast: możliwość wykorzystania kanałów partnerów, wyższy poziom zintegrowania produktów i/lub usług oraz możliwość większej standaryzacji działań. Natomiast wśród zagrożeń największe znaczenie dla badanych podmiotów miały: pojawienie się nowych konkurentów, utrata klientów na rzecz dotychczasowego konkurenta oraz doskonalenie produktów/ 
usług konkurentów. Najniższe oceny uzyskały natomiast: nadmierne uzależnienie się od partnera, utrata kluczowego partnera oraz nawiązanie współpracy przez kluczowego partnera z konkurentem (konkurentami). Przeprowadzone badania wskazują zatem na świadomość czynników i zagadnień związanych przede wszystkim z konkurencyjnością podmiotu, głównie w wymiarze relacji z klientem oraz możliwości zaspokojenia jego potrzeb. Zwrócić należy również uwagę na niskie oceny uzyskane dla zagrożeń dotyczących współpracy z partnerami (jak utrata kluczowego partnera czy nadmierne uzależnienie się od partnera), które mogą wynikać ze stosowania przez badane przedsiębiorstwa outsourcingu, co wymaga posiadania przez dany podmiot specyficznych kompetencji, umożliwiających między innymi nawiązanie oraz zarządzanie relacjami z partnerami outsourcingu.

Jak wspomniano we wprowadzeniu, badaniem objęte zostały dwie kluczowe charakterystyki outsourcingu: jego zakres oraz dojrzałość. Aby dokonać pomiaru zakresu wykorzystania outsourcingu, w pierwszej kolejności zidentyfikowano piętnaście obszarów funkcjonalnych, potencjalnie wchodzących w skład łańcucha wartości badanych podmiotów ${ }^{8}$. W odniesieniu do każdego z obszarów zadano respondentom pytanie dotyczące odsetka czynności objętych outsourcingiem w każdym z nich, z dokładnością do 10\%. Przyjęto tutaj zatem skalę porządkową 11-stopniową - od 0\% (stopień 1) do 100\% (stopień 11). Respondent miał również możliwość wskazania odpowiedzi „proces/funkcja nie występuje w firmie”.

Do pomiaru zakresu wykorzystania outsourcingu w badanych podmiotach wykorzystano autorski Syntetyczny Wskaźnik Outsourcingu (SWO), będący iloczynem szerokości outsourcingu (SO) oraz jego głębokości $(G O)$ :

$$
S W O=S O \times G O
$$

Szerokość outsourcingu (SO) zdefiniowano jako „odsetek obszarów funkcjonalnych wchodzących w skład łańcucha wartości przedsiębiorstwa, w ramach których zastosowano outsourcing" (wartość wskaźnika mieści się w przedziale $<0$, 1>; im wyższa wartość wskaźnika, tym większa liczba obszarów funkcjonalnych objętych outsourcingiem):

$$
S O=\frac{\text { liczba obszarów funkcjonalnych objętych outsourcingiem }}{\text { liczba obszarów wchodzących w skład łańcucha wartości przedsięwzięcia }} \text {. }
$$

8 Szerzej o tej części badań (m.in. charakterystyce poszczególnych obszarów funkcjonalnych) w: J. Drzewiecki, Outsourcing w kontekście obszarów funkcjonalnych polskich przedsiębiorstw - wyniki badań, „Zarządzanie. Teoria i Praktyka” 2015, nr 12(2), s. 11-18. 
Głębokość outsourcingu (GO) zdefiniowano natomiast jako „średni odsetek czynności wydzielonych w ramach funkcji objętych outsourcingiem” (wartość wskaźnika mieści się w granicach $<0,1>$; im wyższa wartość tego wskaźnika, tym wyższy przeciętny odsetek wydzielanych czynności):

$$
G O=\frac{G O_{1}+G O_{2}+\ldots+G O_{N}}{N},
$$

gdzie: $N$ to liczba obszarów objętych outsourcingiem, a $G O_{1}, G O_{2}, \ldots, G O_{N}$ to odsetek czynności wydzielonych w ramach każdego z $N$ obszarów objętych outsourcingiem.

Jak wynika z przyjętego sposobu konstrukcji wskaźnika $S W O$, jego wartość kształtuje się w przedziale $<0,1>$. Dzięki uwzględnieniu obu wskazanych wymiarów - zarówno szerokości outsourcingu, jak i jego głębokości - obliczenie wskaźnika umożliwia obiektywne określenie zakresu wykorzystania outsourcingu w przedsiębiorstwie 9 .

Jako punkt wyjścia do identyfikacji zmiennych odpowiadających za pomiar poziomu dojrzałości outsourcingu przyjęto autorską koncepcję jego dojrzałości, opartą na częstotliwości występowania określonych rozwiązań wynikających $\mathrm{z}$ czterech grup przesłanek:

- realizacji założeń outsourcingu strategicznego,

- formy kontraktu outsourcingowego,

- specyficznych cech relacji z partnerem outsourcingu oraz

- sposobu zarządzania outsourcingiem ${ }^{10}$.

Aby zmierzyć poziom dojrzałości outsourcingu, dokonano identyfikacji łącznie dwudziestu zmiennych: DO1-DO20. Do pomiaru poziomu tych zmiennych wykorzystano sześciostopniową skalę porządkową, przy czym odpowiedź „0” oznaczała „nigdy”, a odpowiedź „5” - „bardzo często”. W dalszej kolejności dokonano agregacji badanych zmiennych, do czego posłużyły analiza czynnikowa ${ }^{11}$ oraz analiza rzetelności ${ }^{12}$. W tabeli 3 przedstawiono zmienne uwzględnione w badaniu poziomu dojrzałości outsourcingu oraz charakterystykę czterech zmiennych syntetycznych będących efektem agregacji.

9 J. Drzewiecki, Outsourcing jako narzędzie zmiany..., s. 228-229.

10 Więcej o wykorzystanej koncepcji dojrzałości outsourcingu w artykule w: J. Drzewiecki, Outsourcing jako narzędzie zmiany..., s. 142-164 oraz s. 203-212.

11 W celu określenia liczby czynników przyjęto łącznie dwa kryteria: poziomy wartości własnych (powyżej 1) oraz kryterium osypiska Catella (R.B. Cattell, The scree test for the number of factors, „Multivariate Behavioral Research” 1996, vol. 1, s. 245-276). Po ustaleniu liczby czynników dokonano ich rotacji, opierając się na metodzie Varimax znormalizowanej.

12 Oceny rzetelności zmiennych zagregowanych dokonano z wykorzystaniem współczynnika alfa-Cronbacha (wartości w przedziale od 0,80 do 0,91 ). 
Tabela 3. Zmienne odpowiedzialne za pomiar dojrzałości outsourcingu oraz charakterystyka zmiennych syntetycznych

\begin{tabular}{|c|c|c|}
\hline $\begin{array}{l}\text { Symbol } \\
\text { zmien- } \\
\text { nej syn- } \\
\text { tetycznej }\end{array}$ & Zmienne wchodzące w skład zmiennej syntetycznej & $\begin{array}{l}\text { Charakterystyka } \\
\text { zmiennej synte- } \\
\text { tycznej }\end{array}$ \\
\hline DO1 & $\begin{array}{l}\mathrm{DO}_{1}: \text { podział zysków/korzyści } \\
\mathrm{DO}_{2}: \text { podział ryzyka/kosztów } \\
\mathrm{DO}_{3}: \text { współdzielenie zasobów ludzkich } \\
\mathrm{DO}_{4}: \text { współdzielenie zasobów rzeczowych } \\
\mathrm{DO}_{5}: \text { prowadzenie wspólnych inwestycji } \\
\mathrm{DO}_{9}: \text { organizowanie nieformalnych spotkań z partnerem } \\
\text { outsourcingu } \\
\mathrm{DO}_{10}: \text { wymiana informacji, wiedzy o charakterze strategicznym } \\
\mathrm{i} / \text { lub kluczowych dla wyników osiąganych przez firmę }\end{array}$ & $\begin{array}{l}\text { Forma } \\
\text { kontraktu, model } \\
\text { wynagradzania } \\
\text { partnera oraz } \\
\text { komunikacja } \\
\text { i wymiana } \\
\text { wiedzy między } \\
\text { partnerami }\end{array}$ \\
\hline DO2 & $\begin{array}{l}\mathrm{DO}_{6}: \text { występowanie umów zawieranych na dłużej niż rok } \\
\mathrm{DO}_{7}: \text { występowanie umów zawieranych na czas nieokreślony } \\
\mathrm{DO}_{8} \text { : występowanie umów zawieranych na okres co najmniej } \\
3 \text { lat }\end{array}$ & $\begin{array}{l}\text { Czas trwania } \\
\text { umowy }\end{array}$ \\
\hline DO3 & $\begin{array}{l}\mathrm{DO}_{11}: \text { analiza ryzyka outsourcingu } \\
\mathrm{DO}_{12}: \text { analiza kosztów utraconych korzyści } \\
\mathrm{DO}_{13}: \text { analiza jakości usług/produktów partnera outsourcingu } \\
\mathrm{DO}_{14}: \text { analiza doświadczenia partnera outsourcingu w realizacji } \\
\text { analogicznych zadań/projektów }\end{array}$ & $\begin{array}{l}\text { Czynności } \\
\text { analityczne } \\
\text { towarzyszące } \\
\text { outsourcingowi }\end{array}$ \\
\hline DO4 & 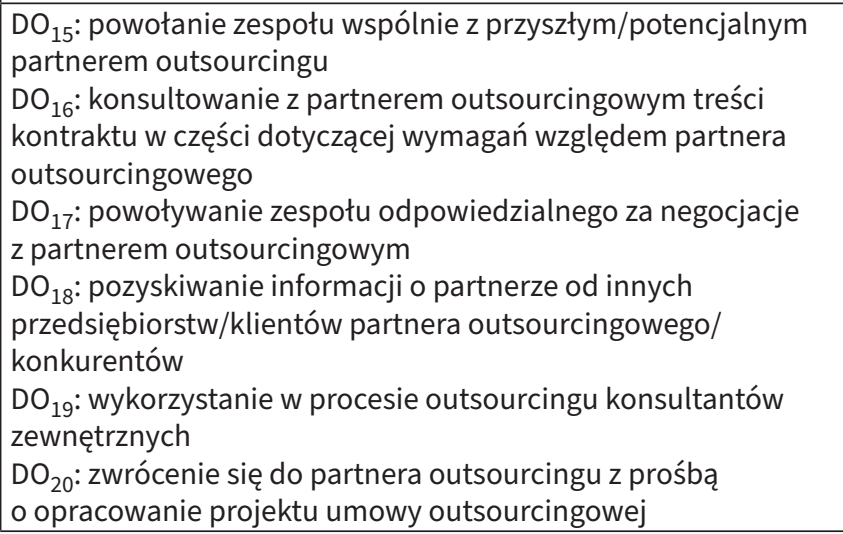 & $\begin{array}{l}\text { Organizacja oraz } \\
\text { zarządzanie } \\
\text { outsourcingiem }\end{array}$ \\
\hline
\end{tabular}

Źródto: opracowanie własne na podstawie J. Drzewiecki, Outsourcing jako narzędzie zmiany..., s. 233-234.

Efektem przeprowadzonej analizy czynnikowej, potwierdzonej weryfikacją rzetelności, było wyodrębnienie czterech zmiennych zagregowanych (DO1-DO4), odpowiadających za poszczególne wymiary dojrzałości outsourcingu (skrajna prawa kolumna tabeli 3). 


\section{Percepcja szans oraz zagrożeń a zakres outsourcingu}

W tabeli 4 przedstawiono rezultaty analizy korelacji między poziomem zmiennych odpowiadających za pomiar znaczenia poszczególnych szans i zagrożeń oraz zakresem outsourcingu mierzonego z wykorzystaniem SWO.

Rezultaty przeprowadzonej analizy wskazują, iż wpływ percepcji szans i zagrożeń na poziom wykorzystania outsourcingu należy uznać za co najwyżej niski. Dla szans istotny statystycznie wpływ wystąpił w sześciu z dwunastu zidentyfikowanych zmiennych, przy czym w każdym z tych przypadków wystąpiła słaba korelacja ${ }^{13}$. Zależność ta okazała się jeszcze słabsza w przypadku zagrożeń, tutaj bowiem potwierdzona została ona statystycznie zaledwie w odniesieniu do trzech zagrożeń z dwunastu. Do zwiększenia zakresu outsourcingu skłaniały badane podmioty przede wszystkim: dążenie do wyższego poziomu zintegrowania produktów i usług, pojawienie się usług (produktów) substytucyjnych oraz doskonalenie produktów/usług konkurentów.

Uzyskane rezultaty w tej części badań pozwalają na wyciągnięcie kilku wniosków. Pierwszy z nich dotyczy prawdopodobnie niskiej świadomości celów realizowanego outsourcingu. Co najwyżej słaba korelacja między znaczeniem szans i zagrożeń a zakresem outsourcingu wskazuje również na możliwe wykorzystanie outsourcingu raczej jako metody rozwiązywania głównie bieżących, operacyjnych problemów niż narzędzia strategicznej zmiany organizacji. Uzyskane rezultaty mogą również wskazywać, iż w odniesieniu do implementacji outsourcingu kluczowy okazuje się nie tyle dobór jego zakresu, ile staranny i możliwie racjonalny wybór poszczególnych obszarów (funkcji, procesów, zadań) objętych wydzieleniem. Jednoznaczna weryfikacja tego zagadnienia wymagałaby jednak przeprowadzenia pogłębionej analizy uwzględniającej podział poszczególnych obszarów na podstawie określonych kryteriów (np. znaczenie danego obszaru w kontekście wartości tworzonej dla klienta), co umożliwiłoby podział funkcji (obszarów) na podstawowe/pomocnicze itp.

13 Do oceny sity zależności między zmiennymi wykorzystano w artykule klasyfikację zaproponowaną przez A. Stanisza, gdzie: 1) wartość współczynnika korelacji dla korelacji „słabej” zawiera się w przedziale od 0,1 do 0,3;2) wartość współczynnika korelacji dla korelacji „przeciętnej” zawiera się w przedziale od 0,3 do 0,5; 3) wartość współczynnika korelacji dla korelacji „wysokiej” zawiera się w przedziale od 0,5 do 0,7; 4) wartość współczynnika korelacji dla korelacji „,bardzo wysokiej” zawiera się w przedziale od 0,7 do 1 (A. Stanisz, Przystępny kurs statystyki z zastosowaniem STATISTICA.PL na przykładach z medycyny, Wydawnictwo StatSoft, Kraków 2006, s. 293). 
Tabela 4. Rezultaty analizy korelacji w układzie: znaczenie szans i zagrożeń - zakres outsourcingu w próbie*

\begin{tabular}{|c|c|c|c|}
\hline Rodzaj szansy & \begin{tabular}{|c|} 
Wartość \\
współczynni- \\
ka korelacji \\
ze zmienną \\
SWO \\
\end{tabular} & Rodzaj zagrożenia & $\begin{array}{c}\text { Wartość } \\
\text { współczynni- } \\
\text { ka korelacji } \\
\text { ze zmienną } \\
\text { SWO }\end{array}$ \\
\hline $\begin{array}{l}\text { Wyższy poziom zintegrowania } \\
\text { produktów i/lub usług }\end{array}$ & $0,23(p=0,000)$ & $\begin{array}{l}\text { Pojawienie się } \\
\text { usług/produktów } \\
\text { substytucyjnych }\end{array}$ & $0,21(p=0,000)$ \\
\hline $\begin{array}{l}\text { Dokładniejsze dopasowanie } \\
\text { produktów/ustug do potrzeb } \\
\text { klientów }\end{array}$ & 0,09 & $\begin{array}{l}\text { Pojawienie się nowych } \\
\text { konkurentów }\end{array}$ & 0,05 \\
\hline \begin{tabular}{|l|} 
Pogorszenie jakości \\
produktów/ustug konkurentów
\end{tabular} & $0,15(p=0,011)$ & $\begin{array}{l}\text { Doskonalenie produktów/ } \\
\text { ustug konkurentów }\end{array}$ & $0,20(p=0,001)$ \\
\hline $\begin{array}{l}\text { Pojawienie się nowych } \\
\text { potencjalnych segmentów } \\
\text { klientów }\end{array}$ & $0,13(p=0,030)$ & $\begin{array}{l}\text { Wystąpienie zakłóceń } \\
\text { w dostawach } \\
\text { zasobów niezbędnych } \\
\text { do działalności podmiotu }\end{array}$ & 0,05 \\
\hline $\begin{array}{l}\text { Odejście klientów } \\
\text { od konkurentów }\end{array}$ & 0,11 & $\begin{array}{l}\text { Nagła utrata kluczowego } \\
\text { zasobu }\end{array}$ & $-0,06$ \\
\hline $\begin{array}{l}\text { Pojawienie się nowych } \\
\text { potencjalnych dostawców/ } \\
\text { partnerów biznesowych }\end{array}$ & 0,02 & $\begin{array}{l}\text { Wzrost cen kluczowych } \\
\text { zasobów }\end{array}$ & 0,06 \\
\hline $\begin{array}{l}\text { Możliwość wykorzystania } \\
\text { kanatów partnerów }\end{array}$ & 0,09 & $\begin{array}{l}\text { Utrata klientów na rzecz } \\
\text { dotychczasowego } \\
\text { konkurenta }\end{array}$ & 0,08 \\
\hline $\begin{array}{l}\text { Możliwość tańszego pozyskania } \\
\text { zasobów kluczowych dla } \\
\text { podmiotu }\end{array}$ & $0,12(p=0,041)$ & $\begin{array}{l}\text { Utrata klientów w efekcie } \\
\text { pojawienia się produktów/ } \\
\text { usług substytucyjnych }\end{array}$ & 0,02 \\
\hline $\begin{array}{l}\text { Możliwość bardziej } \\
\text { efektywnego wykorzystania } \\
\text { posiadanych zasobów }\end{array}$ & 0,09 & $\begin{array}{l}\text { Utrata kluczowego } \\
\text { partnera }\end{array}$ & $-0,01$ \\
\hline $\begin{array}{l}\text { Możliwość większej } \\
\text { standaryzacji działań }\end{array}$ & $0,15(p=0,011)$ & $\begin{array}{l}\text { Nawiązanie współpracy } \\
\text { przez kluczowego partnera } \\
\text { z konkurencją }\end{array}$ & 0,02 \\
\hline $\begin{array}{l}\text { Możliwość wprowadzenia } \\
\text { nowej technologii }\end{array}$ & $0,17(p=0,005)$ & $\begin{array}{l}\text { Nadmierne uzależnienie } \\
\text { się od partnera }\end{array}$ & $0,15(p=0,014)$ \\
\hline Zacieśnienie relacji z klientami & 0,05 & $\begin{array}{l}\text { Pogorszenie relacji } \\
\text { z klientami }\end{array}$ & 0,08 \\
\hline
\end{tabular}

* Kolorem szarym wyróżniono $w$ tabeli korelacje istotne statystycznie na poziomie $p=0,05$. W nawiasach podano dla tych korelacji wartości wspótczynnika $p$.

Źródło: opracowanie własne. 


\section{Percepcja szans oraz zagrożeń a dojrzatość outsourcingu}

W kolejnych dwóch tabelach przedstawiono rezultaty analizy korelacji między szansami (tabela 5) i zagrożeniami (tabela 6) a dojrzałością outsourcingu, również w podziale na zidentyfikowane w badaniu i wskazane w części drugiej artykułu cztery wymiary dojrzałości (odpowiadające zmiennym DO1-DO4).

Uzyskane rezultaty potwierdziły wpływ percepcji szans oraz zagrożeń na wybory dotyczące sposobu realizacji outsourcingu. Istotnie, $w$ badanych podmiotach wysokiemu poziomowi znaczenia szans i zagrożeń towarzyszyło zwiększenie stopnia dojrzałości outsourcingu. Jednocześnie podkreślić należy, iż zależność ta dotyczyła w nieznacznie wyższym stopniu szans niż zagrożeń.

W przypadku niemal wszystkich szans uwzględnionych w badaniu korelacja między zmiennymi kształtowała się na przeciętnym poziomie (wartości w przedziale $0,3-0,4)$. Jedynym wyjątkiem okazała się szansa dotycząca pojawienia się nowych potencjalnych dostawców/partnerów biznesowych $(0,24$, a więc zgodnie z przyjętą $\mathrm{w}$ artykule klasyfikacją - słaba korelacja). Wśród czterech zidentyfikowanych wymiarów dojrzałości outsourcingu percepcja znaczenia szans najsilniej wpłynęła na wymiar dotyczący czynności analitycznych towarzyszących outsourcingowi (zmienna DO3). Najniższe współczynniki korelacji zanotowano natomiast w przypadku formy kontraktu (zmienna DO1). Najsilniej na dojrzałość outsourcingu wpłynęły: szansa wykorzystania kanałów partnerów, możliwość tańszego pozyskania zasobów oraz ich bardziej efektywnego wykorzystania, jak również uzyskanie wyższego poziomu standaryzacji działań.

W przypadku większości zagrożeń (8 z 12) korelacja między percepcją znaczenia zagrożeń a dojrzałością outsourcingu kształtowała się na przeciętnym poziomie (wartości w przedziale $0,3-0,4$ ). W pozostałych czterech przypadkach siłę korelacji należy uznać za słabą (przedział 0,21-0,25). Podobnie jak miało to miejsce w przypadku szans, najsilniej skorelowany okazał się wymiar dojrzałości dotyczący czynności analitycznych towarzyszących outsourcingowi. Zmienna odpowiadająca za pomiar tego wymiaru była istotnie statystycznie skorelowana ze wszystkimi zagrożeniami uwzględnionymi w badaniu, przy czym najsilniejsze korelacje uzyskano dla: wzrostu cen kluczowych zasobów $(0,44)$, wystąpienia zakłóceń $\mathrm{w}$ dostawach zasobów niezbędnych do działalności podmiotu $(0,43)$ oraz pojawienia się nowych konkurentów i doskonalenia produktów/usług konkurentów $(0,41)$. 
Percepcja szans i zagrożeń w polskich przedsiębiorstwach...
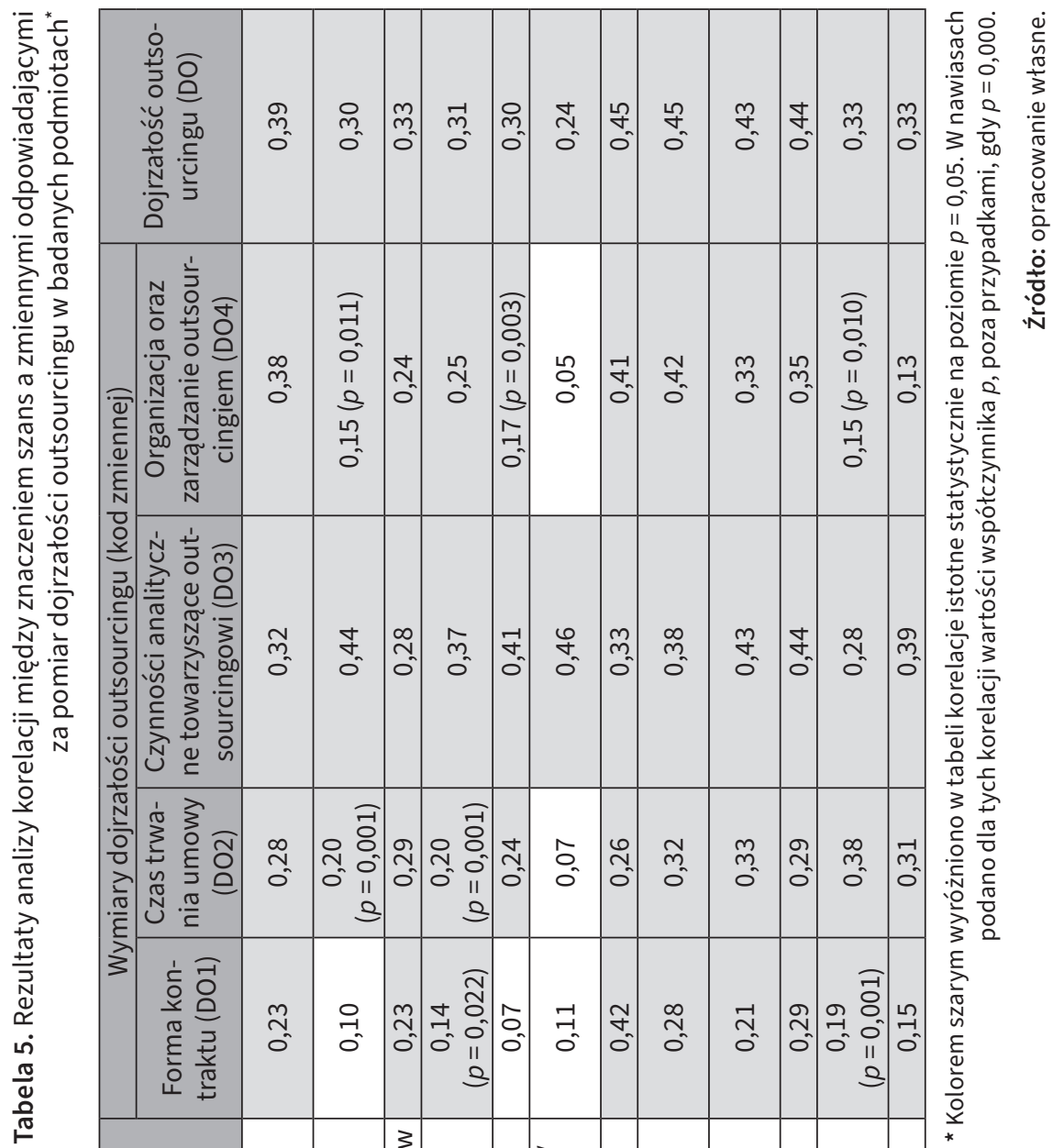

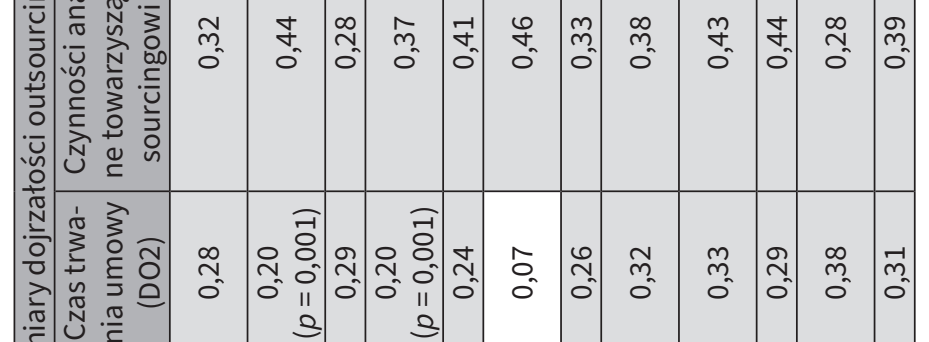

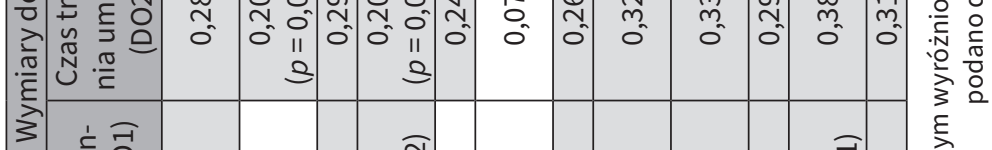

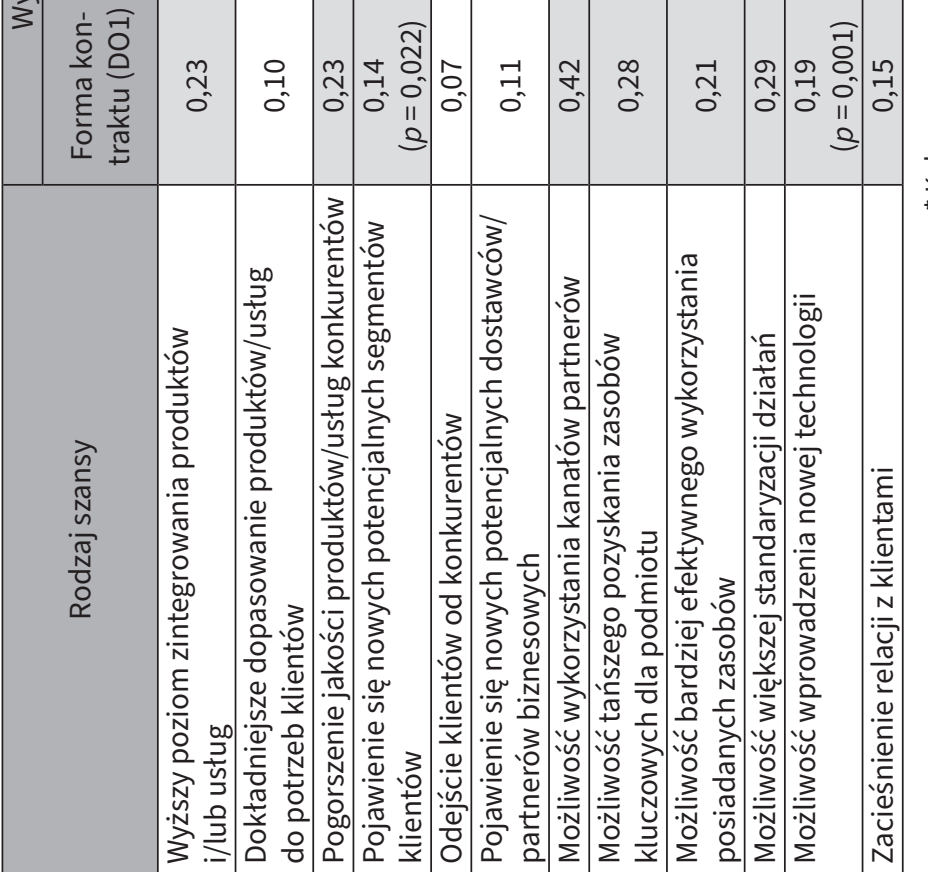




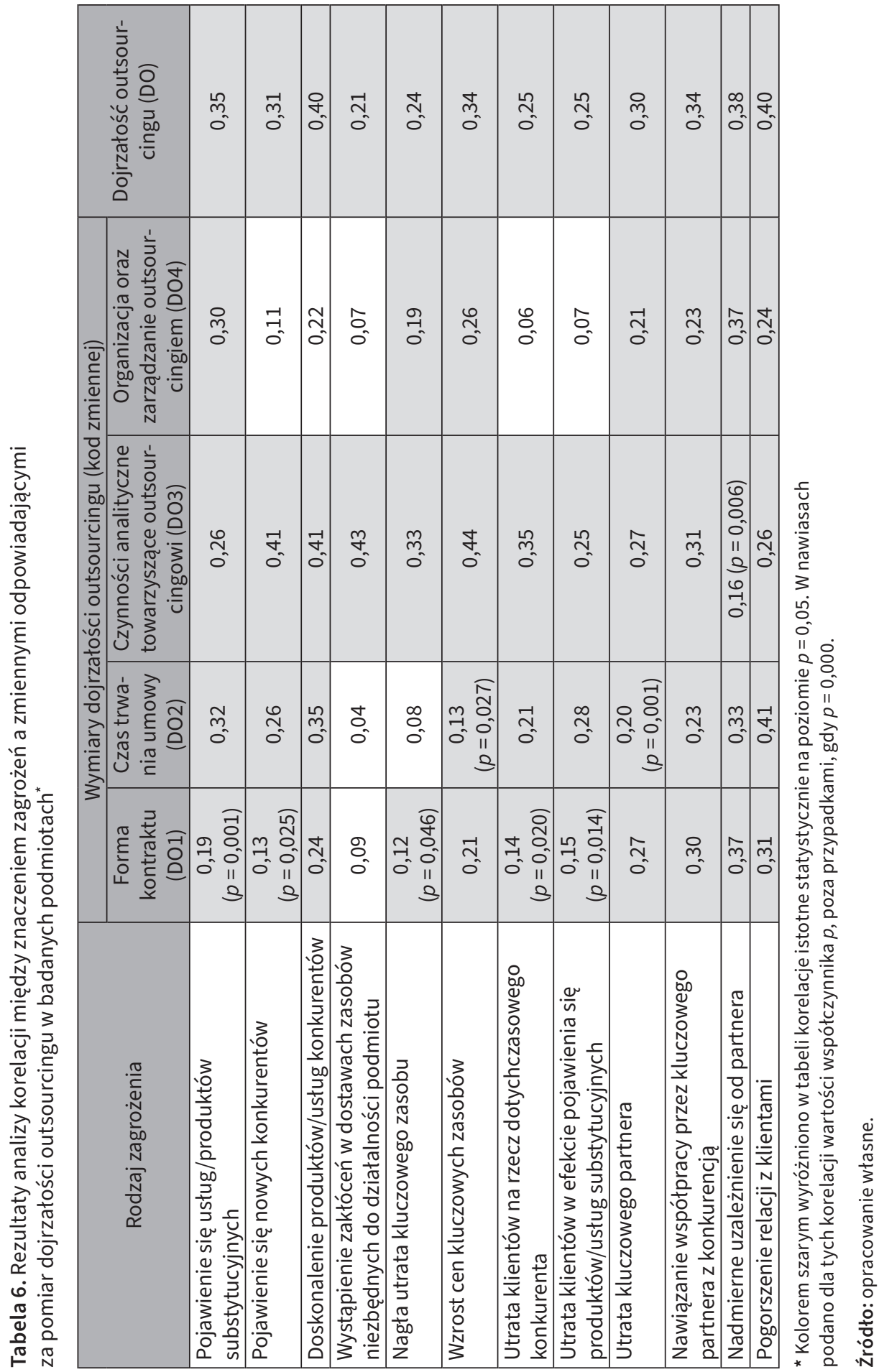




\section{Zakończenie}

Reasumując, przeprowadzone badania potwierdziły wpływ percepcji szans i zagrożeń przede wszystkim na sposób realizacji outsourcingu wyrażany przyjętymi kryteriami jego dojrzałości. Przedsiębiorstwa, które przypisywały uwzględnionym w badaniu szansom oraz zagrożeniom wysokie znaczenie, częściej stosowały bardziej zaawansowane formy outsourcingu (np. dzielenie korzyści i ryzyka), prowadziły staranną analizę działań towarzyszących implementacji tej metody, jak również zacieśniały współpracę z partnerem (wymiar współpracy, zaufania i zaangażowania). Potwierdza to adaptacyjne znaczenie outsourcingu w kontekście szans i zagrożeń występujących w otoczeniu polskich przedsiębiorstw. Jednocześnie nie potwierdzono jednoznacznie zależności statystycznej między percepcją znaczenia szans i zagrożeń a zakresem outsourcingu, co może wskazywać, iż znaczenie w trakcie implementacji outsourcingu ma nie tyle liczba wydzielonych czynności, ile specyfika danego obszaru objętego outsourcingiem.

W tym miejscu wspomnieć należy również o ograniczeniach przeprowadzonych badań, które wynikają przede wszystkim ze specyfiki próby badawczej oraz wykorzystanej w ich trakcie metody gromadzenia danych empirycznych. Badaniem objęto tylko polskie przedsiębiorstwa, co mogło wpłynąć na uzyskane rezultaty, biorąc pod uwagę uwarunkowania kulturowe oraz prawne prowadzonego biznesu, jak również stosunkowo młody wiek polskiej gospodarki.

\section{Bibliografia}

Cattell R.B., The scree test for the number of factors, „Multivariate Behavioral Research” 1996, vol. 1, s. 245-276.

Cyfert S., Granice organizacji, Wydawnictwo Uniwersytetu Ekonomicznego w Poznaniu, Poznań 2012.

Drzewiecki J., Outsourcing application effectiveness in Polish enterprises - research results, „Przegląd Organizacji” 2017, nr 12, s. 67-75.

Drzewiecki J., Outsourcing jako narzędzie zmiany modelu biznesu: perspektywa Business Model Canvas, Wydawnictwo Uniwersytetu Ekonomicznego we Wrocławiu, Wrocław 2019.

Drzewiecki J., Outsourcing w kontekście obszarów funkcjonalnych polskich przedsiębiorstw - wyniki badań, „Zarządzanie. Teoria i Praktyka” 2015, nr 12(2), s. 11-18.

Drzewiecki J., Sposoby realizacji outsourcingu stosowanego w polskich przedsiębiorstwach - wyniki badań, „Organizacja i Kierowanie” 2018, nr 1, s. 113-129.

Stanisz A., Przystępny kurs statystyki z zastosowaniem STATISTICA.PL na przykładach z medycyny, Wydawnictwo StatSoft, Kraków 2006. 


\section{Streszczenie}

Celem artykułu jest identyfikacja oraz analiza wpływu percepcji uwzględnionych w badaniu szans i zagrożeń na zakres oraz dojrzałość outsourcingu stosowanego w polskich przedsiębiorstwach. Artykuł zawiera prezentację wyników badań przeprowadzonych na próbie 281 polskich przedsiębiorstw. Uzyskane rezultaty badań wskazują na co najwyżej słaby poziom korelacji między percepcją szans i zagrożeń a zakresem wykorzystywanego outsourcingu. Jednocześnie przeprowadzone badania potwierdziły wpływ percepcji szans i zagrożeń na dojrzałość outsourcingu, przy czym wpływ ten okazał się nieznacznie silniejszy w przypadku szans niż zagrożeń. Wśród zidentyfikowanych czterech wymiarów dojrzałości outsourcingu percepcja szans i zagrożeń wpłynęła w najwyższym stopniu na sposób realizacji czynności analitycznych towarzyszących jego implementacji.

Słowa kluczowe: outsourcing, szansa, zagrożenie, zakres outsourcingu, dojrzałość outsourcingu

\section{The perception of opportunities and threats in Polish companies within the context of outsourcing use - research results}

\section{Abstract}

The purpose of the paper is to identify and analyse the impact of perceptions of opportunities and threats on the scope and maturity of outsourcing used in Polish enterprises. The article presents the results of quantitative research conducted on a sample of 281 Polish enterprises. The research results indicate at most a weak level of correlation between the perception of opportunities and threats and the scope of the outsourcing used. The study confirmed the impact of perception of opportunities and threats on outsourcing maturity, with this impact being slightly stronger for opportunities than threats. Among the four dimensions of outsourcing maturity identified, the perception of opportunities and threats had the greatest impact on the analytical activities accompanying its implementation.

Keywords: outsourcing, opportunity, threat, outsourcing scope, outsourcing maturity 